\title{
Zinc Accumulation Characteristics of Two Exophiala Strains and Their Antioxidant Response to $\mathrm{Zn}^{2+}$ Stress
}

\author{
Y. H. Diao", T. Li", Z. W. Zhao ${ }^{*}$ \\ Laboratory of Conservation and Utilization for Bioresources, Key Laboratory of Microbial Diversity in Southwest China, Ministry of \\ Education, Yunnan University, Kunming, China. \\ Email: "haozhw@ynu.edu.cn
}

Received January $16^{\text {th }}, 2013$; revised February $19^{\text {th }}, 2013$; accepted March $23^{\text {rd }}, 2013$

Copyright (C) 2013 Y. H. Diao et al. This is an open access article distributed under the Creative Commons Attribution License, which permits unrestricted use, distribution, and reproduction in any medium, provided the original work is properly cited.

\begin{abstract}
Zinc is an essential element, which is toxic for organisms in their natural environments in excessive amounts. The zinc accumulation characteristics of a $\mathrm{Zn}$-tolerant strain $\left(\mathrm{H} 93, \mathrm{EC}_{50}=1010 \mathrm{mg} \cdot \mathrm{L}^{-1} \mathrm{Zn}^{2+}\right)$ and a $\mathrm{Zn}$-sensitive strain (B40-3, $\left.\mathrm{EC}_{50}=26 \mathrm{mg} \cdot \mathrm{L}^{-1} \mathrm{Zn}^{2+}\right)$, Exophiala spp. and their antioxidant response to $\mathrm{Zn}^{2+}$ stress were comparatively characterized. Under their respective $\mathrm{Zn}^{2+}$ median effective concentrations, $\mathrm{H} 93$ absorbed 2.5 -fold and accumulated 5.2-fold more $\mathrm{Zn}$ than B40-3. An elution experiment using $\mathrm{CaCl}_{2}$ revealed that $\mathrm{Zn}$ mainly accumulated intracellularly in the mycelia of the two fungal strains. The modulation of antioxidant components and antioxidant enzyme activities of the two fungal strains were comparatively analyzed under different $\mathrm{Zn}^{2+}$ concentrations. The activity of the total superoxide dismutase, peroxidase, and glutathione of $\mathrm{H} 93$ was always higher than that of B40-3, and the malondialdehyde content in $\mathrm{H} 93$ was also higher than that of B40-3. The current results suggested that the $\mathrm{Zn}$ tolerance of Exophiala strain may be attributed to their various instinctive behaviors with different rates of $\mathrm{Zn}$ accumulation and modulation of antioxidant components.
\end{abstract}

Keywords: Exophiala; Zinc-Sensitive and Zinc-Tolerant Strains; Accumulation; Antioxidant System; Dark Septate Endophyte (DSE)

\section{Introduction}

Among the dematiaceous fungi responsible for human or animal phaeohyphomycosis, the Exophiala genus is a well-known etiologic agent that presently includes several species considered as opportunistic pathogens [1-3]. In recent years, Exophiala fungi have been repeatedly reported as root-associated endophytic fungi, which have also been designated as dark septate endophytes (DSEs) $[4,5]$. Under low-power light microscopy, their pigmented structures, including dematiaceous septate hyphae and microsclerotia (aggregation of dark, thick-walled, and closely packed inflated cells), are easily visible colonizing the root cortex, the epidermis, and root surfaces intercellularly and intracellularly [6-8]. More data from field studies reveal that DSE comprise ascomycetous fungi which have a ubiquitous distribution and wide range of host plants $[9,10]$ and they are especially common in stressful environments [11,12]. Previous studies in our

\footnotetext{
${ }^{*}$ Y. H. Diao and T. Li contributed equally to this work.

${ }^{\#}$ Corresponding author.
}

laboratory found that most plants that naturally developed in a $\mathrm{Pb}-\mathrm{Zn}$ slag heap in Southwest China are commonly colonized by DSEs [13] and DSEs isolated from these areas possess an inherent tolerance to heavy metals [14]. Under metal-polluted soils, the metal tolerant DSE strain Exophiala pisciphila $\mathrm{H} 93$ clearly alleviated the deleterious effects of excessive heavy metal ions and its colonization improved the metal tolerance of maize [15].

Zinc is an essential micronutrient required for a wide variety of cellular processes. However, excessive $\mathrm{Zn}$ can be toxic to organisms [16], which is proposed in the 13 metal contamination list by the US Environmental Protection Agency (US EPA) [17]. Excessive heavy metals are known to induce oxidative stress by generating high concentrations of reactive oxygen species (ROS), such as superoxide radical $\left(\mathrm{O}_{2}^{-}\right)$, hydroxyl radical $(\mathrm{HO} \bullet)$, and hydrogen peroxide $\left(\mathrm{H}_{2} \mathrm{O}_{2}\right)$, and affect the activity of endogenous enzymes, or membrane polyunsaturated fatty acids, which leads to lipid peroxidation and malondialdehyde (MDA) formation $[18,19]$. Thus, MDA is considered as a cytotoxic product of lipid peroxidation and 
an indicator of free radical production and consequent tissue damage. If they are not effectively neutralized by the antioxidant defense system in tissues, oxidative stress results in direct damage to lipids, proteins, and DNA, and eventually initiates cell damage [20,22]. The antioxidant defense system of organisms is composed of different antioxidant components, including a non-enzymatic antioxidant system, e.g., carotenoids, ascorbate, and glutathione (GSH), and an enzymatic anti-oxidative system, e.g., total superoxide dismutase (T-SOD), catalase (CAT), and peroxidase (POD) [23-25]. Under abnormal circumstances, organisms display several antioxidant enzymes against ROS, and enhance protective processes, such as the accumulation of compatible solutes and increased activity of detoxifying enzymes [26]. Changes in the activity of these defense systems have been proposed as biomarkers for contaminant-mediated pro-oxidant challenge [27].

More detailed studies of the interactions between DSEs and their host plants reveal they have a beneficial role in plant growth and survival in various stressful environments [28], and DSE colonization improved the tolerance of host plants under various abiotic stresses such as metal contaminants, heat, salinity and drought $[15,29$, 30]. However, the current knowledge on the instinctive behavior of DSEs against metal toxicity is still limited. In the present study, a Zn-sensitive and a Zntolerant Exophiala spp. were targeted and their growth, $\mathrm{Zn}$ accumulation characteristics, and their modulation of antioxidant components and antioxidant enzyme activities were comparatively analyzed under different $\mathrm{Zn}^{2+}$ supplements.

\section{Materials and Methods}

\subsection{Exophiala Spp. Strains and Zn EC50}

In the current study, two DSE fungi were compared: the Zn-tolerant Exophiala pisciphila H93 (referred to as H93), and the Zn-sensitive B40-3 culture identified as Exophiala sp. by sequencing their internal transcribed spacer and large subunit rDNA, and phylogenetic analysis. H93 was isolated from the roots of Arundinella bengalensis that naturally grows in an ancient $\mathrm{Pb}-\mathrm{Zn}$ slag heap at Huize, Yunnan Province, China and the Zn-sensitive B40-3 culture was isolated from the non-metal contaminated roots of Eupatorium adenophorum in the tropical rain forest of Xishuangbanna, Yunnan Province, China. Two DSE strains were deposited in Agricultural Culture Collection of China with accession number ACCC32496 (H93) and in China Forestry Culture Collection Center (CFCC89522) (B40-3) respectively.

The $\mathrm{Zn}$ tolerance of the two fungal strains was determined and expressed as the median effective concentration $\left(\mathrm{EC}_{50}\right)$ of $\mathrm{Zn}^{2+}$, which results in inhibition of $50 \%$ clonal growth. Modified Melin-Norkrans (MMN) liquid media $\left(\mathrm{CaCl}_{2} \cdot 2 \mathrm{H}_{2} \mathrm{O}, 0.05 \mathrm{~g} \cdot \mathrm{L}^{-1}\right.$; maltose, $3.0 \mathrm{~g} \cdot \mathrm{L}^{-1} ; \mathrm{NaCl}$,
$0.025 \mathrm{~g} \cdot \mathrm{L}^{-1}$; glucose, $10.0 \mathrm{~g} \cdot \mathrm{L}^{-1} ; \mathrm{K}_{2} \mathrm{HPO}_{4}, 0.5 \mathrm{~g} \cdot \mathrm{L}^{-1}$; VB1, $0.1 \mathrm{mg} \cdot \mathrm{L}^{-1} ; \mathrm{MgSO}_{4}, 0.15 \mathrm{~g} \cdot \mathrm{L}^{-1} ; 1 \% \mathrm{FeCl}_{3}$ solution, 1.2 $\mathrm{ml} \cdot \mathrm{L}^{-1} ; \mathrm{NaNO}_{3}, 3.0 \mathrm{~g} \cdot \mathrm{L}^{-1}$; and $\left(\mathrm{NH}_{4}\right)_{2} \mathrm{HPO}_{4}, 0.25 \mathrm{~g} \cdot \mathrm{L}^{-1}$; $\mathrm{pH} 5.5)$ were prepared and amended with the desired $\mathrm{Zn}^{2+}$ concentrations [31]. Then, $50 \mathrm{~g} \cdot \mathrm{L}^{-1} \mathrm{Zn}^{2+}\left(\mathrm{ZnSO}_{4} \cdot 7 \mathrm{H}_{2} \mathrm{O}\right)$ stock solution was diluted to yield the desired concentrations $(0,200,400,600,800,1000,1500$, and 2000 $\mathrm{mg} \cdot \mathrm{L}^{-1}$ for $\mathrm{H} 93$, and $0,25,5075,100$, and $200 \mathrm{mg} \cdot \mathrm{L}^{-1}$ for B40-3). Each $250 \mathrm{~mL}$ Erlenmeyer flask containing $100 \mathrm{~mL}$ of the prepared media was inoculated with a fungal disk $(\Phi 0.6 \mathrm{~cm})$ cut from a 14-day-old PDA culture. The Erlenmeyer flasks were incubated at $28^{\circ} \mathrm{C}$ and 120 rpm agitation for $7 \mathrm{~d}$ and then filtered through a mediumspeed qualitative filter paper (Hangzhou Special Paper Co., Ltd., Hangzhou, China). Then, the mycelia were dried to a constant weight in an oven at $80^{\circ} \mathrm{C}$ and weighed. The $\mathrm{EC}_{50}$ value was calculated by fitting a linear regression to the results from the inhibition of the biomass of the two fungal strains [32].

\subsection{Biosorption and Accumulation of $\mathrm{Zn}$ by the Two Fungal Strains}

To determine the hyphal biosorption and accumulation of $\mathrm{Zn}$, the two fungal strains were incubated under different $\mathrm{Zn}^{2+}$ supplements at $28^{\circ} \mathrm{C}$ and agitated at $120 \mathrm{rpm}$ for $7 \mathrm{~d}$. Then, the mycelia in the $100 \mathrm{~mL}$ cultures were harvested, washed three times with $100 \mathrm{~mL}$ of distilled water, and as much liquid as possible was removed using a filter paper-covered Buchner funnel (medium-speed qualitative filter paper) using a vacuum pump (Yuhua Instrument Co., Ltd., Zhengzhou, China). Then 0.5 g mycelia were bathed for $30 \mathrm{~min}$ in $100 \mathrm{mM} \mathrm{CaCl}_{2}$ solution $(100 \mathrm{~mL})$ at $28^{\circ} \mathrm{C}$ and $120 \mathrm{rpm}$ agitation [16]. Then, the zinc concentrations in the $\mathrm{CaCl}_{2}$ eluting solution (for biosorption) and in the mycelia (for accumulation) were determined via a flame atomic absorption spectrometer (FAAS) using a Z2000 polarized Zeeman atomic absorption spectrophotometer (Hitachi, Japan). For the hyphal accumulation of $\mathrm{Zn}, 50 \mathrm{mg}$ of the mycelia was digested using $\mathrm{HNO}_{3}+\mathrm{HClO}_{4}$. Quantification was carried out with a calibration curve using a graded series of diluted $\mathrm{Zn}$ solutions $\left(0,0.1,0.2,0.4,0.8\right.$, and $\left.1.2 \mu \mathrm{g} \cdot \mathrm{mL}^{-1}\right)(\mathrm{GSW} 08620$, National Research Center for Certified Reference Materials, China). The hollow cathode lamp was operated at $5 \mathrm{~mA}$ and the analytical wavelength was set to $213.9 \mathrm{~nm}$ for the detection of $\mathrm{Zn}$ [15].

\subsection{Antioxidant Systems}

Under different $\mathrm{Zn}^{2+}$ supplements, the mycelia of the two fungal strains were harvested and washed as described above. The mycelia were then flash-frozen in liquid nitrogen and ground in a chilled mortar and pestle. Then, $0.5 \mathrm{~g}$ of the ground powder was collected into a new ster- 
ile centrifuge tube and suspended in $5 \mathrm{~mL}$ Tris buffer solution $(50 \mathrm{mM}, \mathrm{pH} 7.8)$ and centrifuged at $8000 \mathrm{rpm}$ for $30 \mathrm{~min}$ at $4^{\circ} \mathrm{C}$. The supernatant liquid was collected and used as cell-free extracts for the analysis of antioxidant activities [33]. T-SOD, POD, MDA, and GSH were determined according to the protocols of the Nanjing Jiancheng Bioengineering Institute (Nanjing, China) included in the kits.

\subsection{Statistical Analysis}

Each treatment of all above experiments was conducted in triplicate and the average values were used in the data analysis. The effects of $\mathrm{Zn}$ on mycelial biomass, mycelial heavy metal content, and hyphal enzyme activity are expressed as mean \pm standard deviation (SD). The significant differences among the treatments were analyzed using a one-way ANOVA with statistical significance at $P$ $<0.05$ based on a least significant difference multiple range test.

\section{Results and Discussion}

The growth of the two fungal strains was not restricted at lower $\mathrm{Zn}$ concentrations. However, the biomass of the two fungal strains decreased with increasing $\mathrm{Zn}^{2+}$ supplements (Figure 1). Our overall results were also in accordance with the original knowledge on Zinc. $\mathrm{Zn}$ is essential for the normal growth and development of almost all organisms including filamentous fungi, because it serves as a cofactor in many physiologic processes. However, it can be highly toxic at excessive levels [34]. Meanwhile, the two fungal strains showed significant differences in their $\mathrm{Zn}$ tolerance. $\mathrm{H} 93$ showed $50 \%$ growth inhibition $\left(\mathrm{EC}_{50}\right)$ at $1010 \mathrm{mg} \cdot \mathrm{L}^{-1} \mathrm{Zn}$, whereas the biomass of $\mathrm{B} 40-3$ was reduced by $50 \%$ at $26 \mathrm{mg} \cdot \mathrm{L}^{-1}$ of $\mathrm{Zn}\left(\mathrm{EC}_{50}\right.$ for $\left.\mathrm{B} 40-3\right)$. Differences in zinc tolerance were found across different

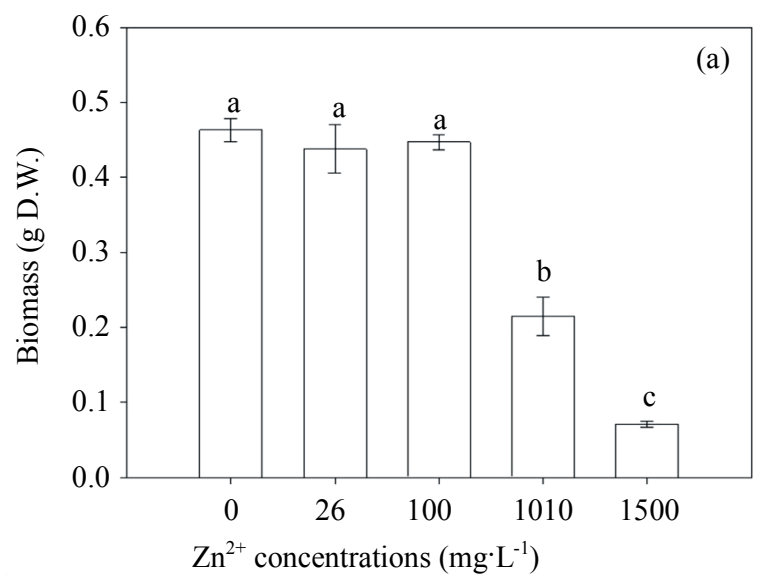

organisms and also across different strains of a given species, and $\mathrm{Zn}$ tolerance may be linked to their physiologic adaptation and the selection of their environment [35]. Cairney et al. [36] reported that the $\mathrm{EC}_{50}$ of $\mathrm{Zn}$ for ericoid mycorrhizal endophytes from Woollsia pungens is only $1.08 \mathrm{mg} \cdot \mathrm{L}^{-1}$. However, the $\mathrm{EC}_{50}$ of $\mathrm{Zn}$ for Aspergillus niger isolated from polluted sites reach $1625 \mathrm{mg} \cdot \mathrm{L}^{-1}$ [37]. In pioneer pine forests at 14 different locations along a Zn pollution gradient, Colpaert et al. [35] also reported that the severe $\mathrm{Zn}$ pollution surrounding $\mathrm{Zn}$ smelters clearly triggers the evolution of increased $\mathrm{Zn}$ tolerance in pioneer Suilloid fungi. With increasing distance from the $\mathrm{Zn}$ smelters, the frequency of $\mathrm{Zn}$-tolerant genotypes decreases. The $\mathrm{EC}_{50}$ of the $\mathrm{Zn}$-tolerant ectomycorrhizal basidiomycete Suillus luteus isolate (UH-Slu-Lm8) obtained from a heavy metal polluted site in Lommel is approximately nine fold higher than that of a $\mathrm{Zn}$-sensitive isolate (UH-Slu-P13) obtained from a non-polluted site in Paal [38]. In the current study, H93 was isolated from an ancient lead and zinc slag heap [14], and exposure to heavy metals may trigger its physiological adaptation to $\mathrm{Zn}$ stress [35].

Mycelial biosorption and intracellular accumulation of $\mathrm{Zn}$ in H93 and B40-3 increased with the increasing extracellular $\mathrm{Zn}$ concentrations (Figure 2). The intracellular $\mathrm{Zn}$ accumulation was higher than that of the adsorptively bound $\mathrm{Zn}$ in both strains. Furthermore, the biosorption of $Z n$ (presumed in the cell wall) and intracellular $\mathrm{Zn}$ of the $\mathrm{Zn}$-tolerant strain (H93) were signficantly higher than those of the $\mathrm{Zn}$-sensitive strain (B40-3), which suggested that both the cell wall and cytoplasm contribute to the $\mathrm{Zn}$ tolerance of Exophiala strains. In contrast to the three fold $\mathrm{Zn}$ biosorption by $\mathrm{H} 93$ compared with that by B40-3, the $\mathrm{Zn}$ accumulation of the two fungal strains was almost the same at $26 \mathrm{mg} \cdot \mathrm{L}^{-1} \mathrm{Zn}$. The intracellular $\mathrm{Zn}$ accumulation of $\mathrm{H} 93$ was 5.24-fold higher

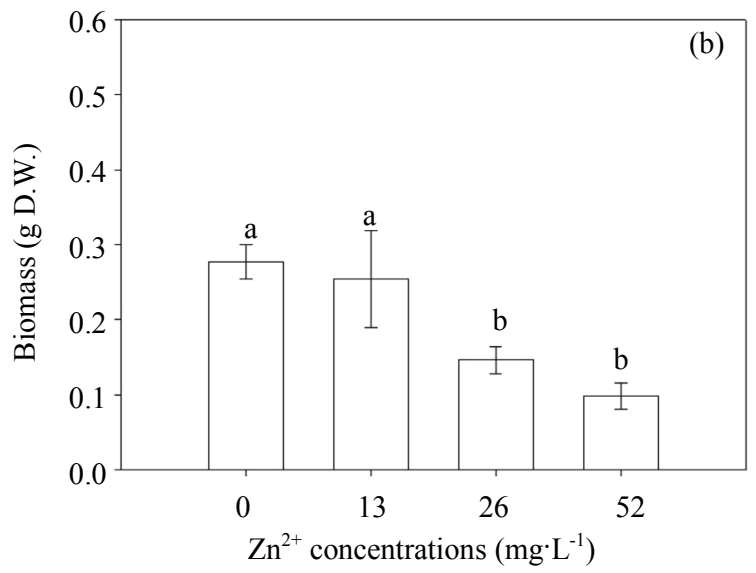

Figure 1. Effect of $\mathrm{Zn}^{2+}$ supplementation on the biomass of $\mathrm{H93}$ (a) and B40-3 (b) in modified MMN liquid cultures at $28^{\circ} \mathrm{C}$, agitated at $120 \mathrm{rpm}$ for $7 \mathrm{~d}$. 

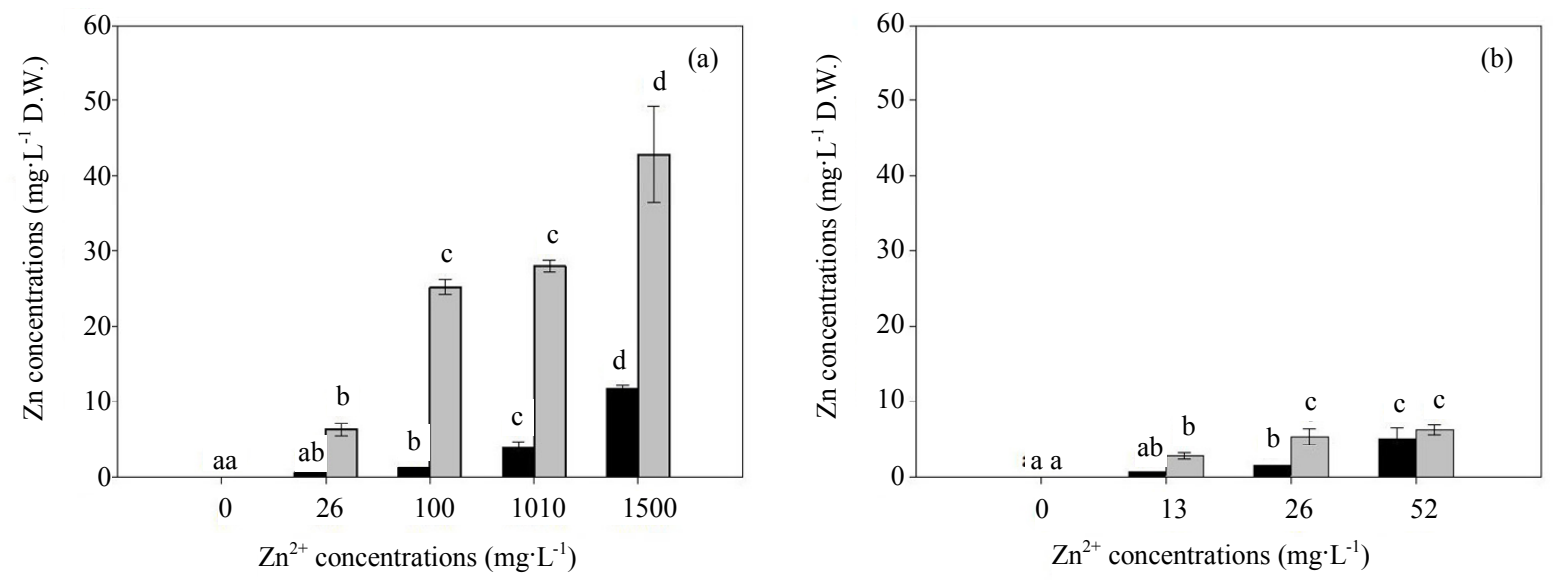

Figure 2. Zn biosorption ( $\square$ ) and accumulation $(\square)$ in $\mathrm{H93}(\mathrm{a})$ and B40-3 (b) under different $\mathrm{Zn}^{2+}$ stress.

than that of $\mathrm{B} 40-3$ at their $\mathrm{EC}_{50}$ respectively; However, the biosorption by $\mathrm{H} 93$ was only 2.52 -fold that by B40-3 (Figure 2). Consequently, although more $\mathrm{Zn}$ ions were uptaked and accumulated by the H93 mycelia than B40-3, less growth restriction occurred under the same metal stress. The prevailing theory argues that the binding of metals to the cell wall and compartmentalization in the vacuoles may be essential mechanisms for metal detoxification in various fungi $[16,39,40]$. Through energy-dispersive X-ray spectroscopy, González-Guerrero et al. [41] found that heavy metals accumulated mainly in the mycorrhizal fungal cell wall and in the vacuoles, whereas minor changes in metal concentrations were detected in the cytoplasm. Subsequent experiments showed that many of the proteins involved in metal transport and homeostasis, such as ZRT2, play essential roles in Zn nutriation and resistance in eukaryotic cells $[42,43]$. At $52 \mathrm{mg} \cdot \mathrm{L}^{-1}$ $\mathrm{Zn}$, the $\mathrm{Zn}$ accumulation and biosorption concentrations of B40-3 were almost the same, which suggested higher $\mathrm{Zn}$ concentrations might have disrupted the balance and severely damage the cell wall of B40-3 and further inhibited its growth.

In biochemical systems, Zn exerts its antioxidant properties, which appear to be mostly independent of $\mathrm{Zn}$ metalloenzyme activity [44]. However, excess Zn imposes severe effects on biomass production, biosorption, accumulation, and oxidative activities. Malondialdehyde (MDA) is a cytotoxic product of lipid peroxidation and an indicator of free radical production and consequent tissue damage [45]. Thus, the influence of $\mathrm{Zn}$ on the MDA production in the mycelia of the two fungal strains is determined and shown in Figure 3. The MDA content significantly increased when exposed to excess $\mathrm{Zn}$ after $7 \mathrm{~d}$, and the effects of high $\mathrm{Zn}$ concentrations obviously enhanced the MDA content. The MDA content of H93 was 2.7-fold higher than that of B40-3 at their $\mathrm{EC}_{50}$ (Figures 3(a) and (b)). The current study suggested that free radical generation increased in H93 and B40-3 under Zn stress, as indicated by MDA. The MDA content of the two fungal strains increased with increasing $\mathrm{Zn}$ concentrations in the culture medium, which indicates concentration-dependent free radical generation similar to the effect of heavy metals on the cyanobacterium Spirulina platensis-S5 [26] and higher plants [46,47].

In general, the activated antioxidant defense system of cells is reportedly a compensatory mechanism for various organisms and the modulation of the antioxidant status is an important adaptive response to heavy metals [48]. Penninckx [49] found that GSH plays an important role as a cellular redox buffer when yeast cells are under environmental stress. At different $\mathrm{Zn}$ concentrations, the elevated extracellular $\mathrm{Zn}$ concentrations increased the GSH levels in both fungal strains, and showed a positive correlation between intracellular GSH content and extracellular Zn concentrations (Figures 3(c) and (d)). At their $\mathrm{EC}_{50}$, GSH in the H93 mycelia increased to $134 \%$ and $104 \%$ for B40-3 compared with their mycelia without $\mathrm{Zn}$ stress. The GSH content of H93 was 2.94-fold higher than that of B40-3 at their EC $_{50}$ (Figures 3(c) and (d)).

In the present study, the correlation between external Zn concentration and antioxidant level was analyzed. The effects of excess $\mathrm{Zn}$ on the T-SOD and POD activity in the mycelia of both fungal strains are shown in Fig. 4. When the two fungal strains grew in the MMN liquid media without $\mathrm{Zn}$, the T-SOD and POD activity in the mycelia were not significantly different and their contents were $16.33 \mathrm{U} \cdot \mathrm{mg}^{-1}$ and $4.774 \mathrm{U} \cdot \mathrm{mg}^{-1}$ protein for $\mathrm{H} 93$, and $18.443 \mathrm{U} \cdot \mathrm{mg}^{-1}$ and $6.471 \mathrm{U} \cdot \mathrm{mg}^{-1}$ protein for B40-3, respectively. However, the activity of the two antioxidant enzymes in the two fungal strains increased rapidly with the external $\mathrm{Zn}$ contaminant concentrations. The T-SOD and POD activity of $\mathrm{H} 93$ were 1.32 -fold and 1.86-fold higher than that of $\mathrm{B} 40-3$ at their $\mathrm{EC}_{50}$, respectively (Figure 4). Presumably, T-SOD and POD play effective roles in protecting the two fungal strains from the ROS induced by high $\mathrm{Zn}^{2+}$ concentrations [50,51]. In 

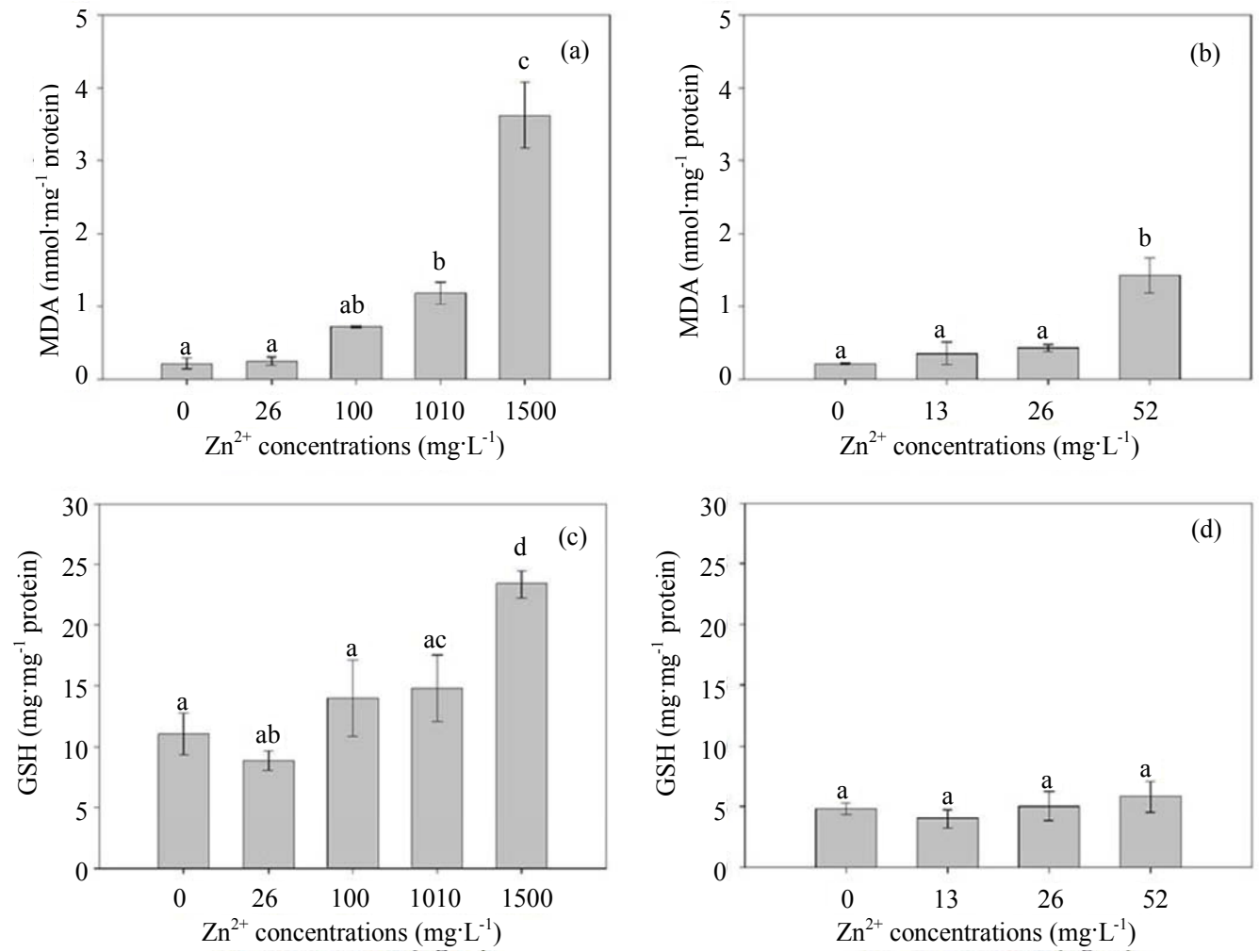

Figure 3. Effect of $\mathrm{Zn}^{2+}$ on the MDA and GSH content of the Zn-tolerant DSE strain H93 (A, C) and the Zn-sensitive DSE strain B40-3 (B, D).
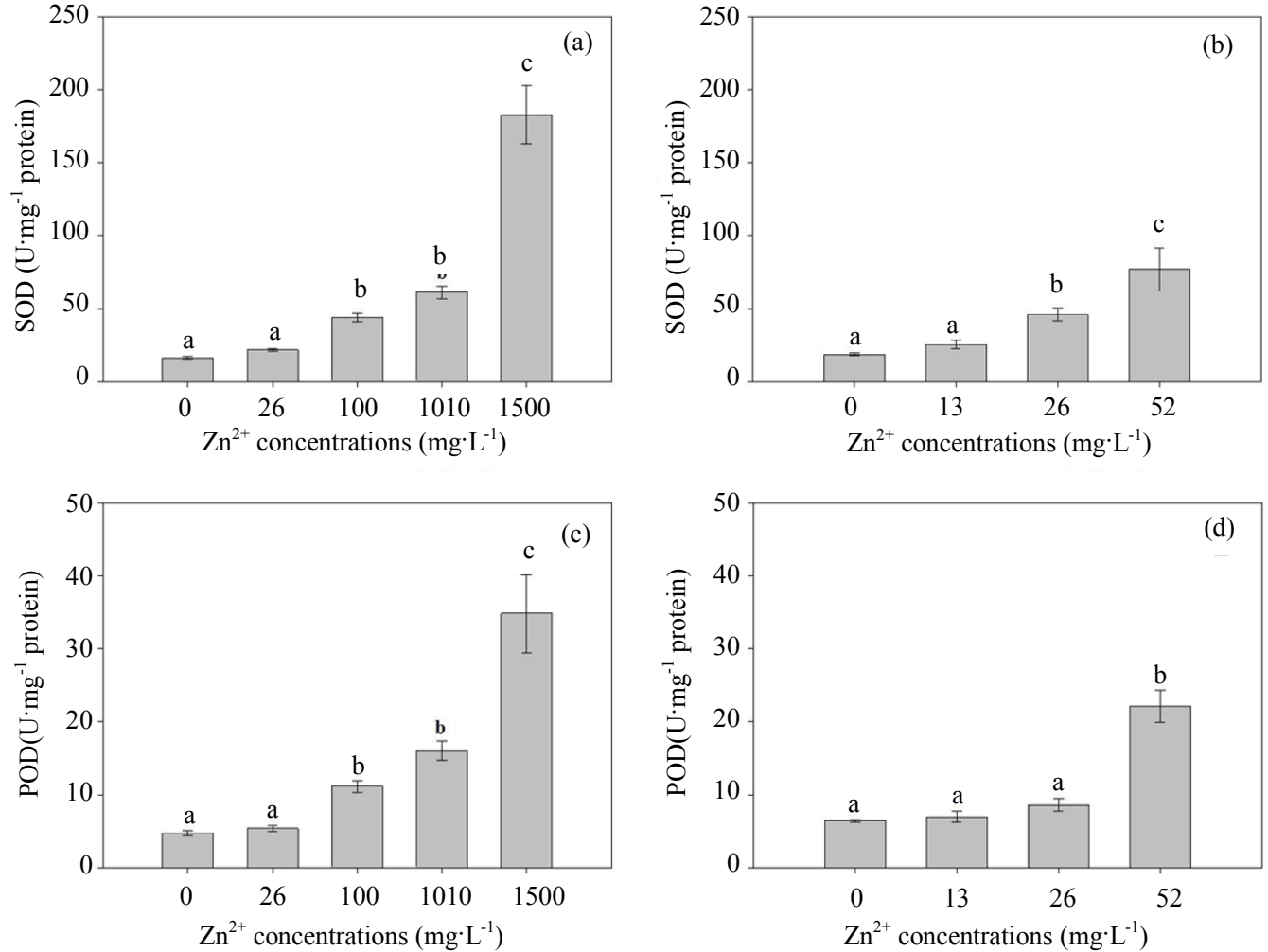

Figure 4. Response of the T-SOD and POD to the elevated $\mathrm{Zn}^{2+}$ stress in the $\mathrm{Zn}$-tolerant DSE strain H93 (A, C) and the Zn-sensitive DSE B40-3 (B, D). 
summary, the present study provides direct evidence of oxidative stress-mediated Zn toxicity in Exophiala strains. Differences in $\mathrm{Zn}$ accumulation and tolerance were observed within Exophiala strains, and physiologic adaptation and environmental selection may contribute to this difference. The cell wall and cytoplasm play effective roles in the $\mathrm{Zn}$ tolerance of Exophiala strains, and the antioxidant system in the cytoplasm, especially T-SOD and POD play important roles.

\section{Acknowledgements}

We would like to thank Dr. Fang-dong Zhan (College of Resources and Environment, Yunnan Agricultural University, PR China) for his helping with the FAAS analysis of zinc. This research was financially supported by National Natural Science Foundation of China (31160009, 41161083) and Young Academic and Technical Leader Raising Foundation of Yunnan Province (2012HB006).

\section{REFERENCES}

[1] M. R. McGinnis and L. Ajello, "A New Species of Exophiala Isolated from Channel Catfish," Mycologia, Vol. 66, No. 3, 1974, pp. 518-520. doi:10.2307/3758495

[2] J. S. Zeng and G. S. De Hoog, "Exophiala spinifera and Its Allies: Diagnostics from Morphology to DNA Barcoding," Medical Mycology, Vol. 46, No. 3, 2008, pp. 193-208. doi:10.1080/13693780701799217

[3] C. Munchan, O. Kurata, S. Wada, K. Hatai1, A. Sano, K. Kamei and N. Nakaoka, "Exophiala xenobiotica Infection in Cultured Striped Jack, Pseudocaranx dentex (Bloch \& Schneider), in Japan," Journal of Fish Diseases, Vol. 32, No. 10, 2009, pp. 893-900. doi:10.1111/j.1365-2761.2009.01068.x

[4] H. D. Addy, M. M. Piercey and R. S. Currah, "Microfungal Endophytes in Root," Canadian Journal of Botany, Vol. 83, No. 1, 2005, pp. 1-13. doi:10.1139/b04-171

[5] W. Wang, "Dark Septate Endophytespp. Taxonomy and Distribution," PhD Dissertation, University of Alberta, Edmonton, 2009.

[6] A. Jumpponen and J. M. Trappe, "Dark Septate Endophytes: A Review of Facultative Biotrophic Root-Colonizing Fungi," New Phytologist, Vol. 140, No. 4, 1998, pp. 295-310. doi:10.1046/j.1469-8137.1998.00265.x

[7] J. R. Barrow, "Atypical Morphology of Dark Septate Fungal Root Endophytes of Bouteloua in Arid Southwestern USA Rangelands," Mycorrhiza, Vol. 13, No. 5, 2003, pp. 239-247. doi:10.1007/s00572-003-0222-0

[8] Z. L. Yuan, C. L. Zhang, F. C. Lin and C. P. Kubicek, "Identity, Diversity, and Molecular Phylogeny of the Endophytic Mycobiota in the Roots of Rare Wild Rice (Oryza granulate) from a Nature Reserve in Yunnan, China," Applied and Environmental Microbiology, Vol. 76, No. 5, 2010, pp. 1642-1652. doi:10.1128/AEM.01911-09

[9] A. Jumpponen, "Dark Septate Endophytes-Are They
Mycorrhizal?" Mycorrhiza, Vol. 11, No. 4, 2001, pp. $207-$ 211. doi:10.1007/s005720100112

[10] M. J. Liu, X. T. Zhang and Z. W. Zhao, "Advances in the Research of Dark Septate Endophytes," Mycosystema, Vol. 28, No. 6, 2009, pp. 888-894.

[11] K. Mandyam and A. Jumpponen, "Seeking the Elusive Function of the Root-Colonising Dark Septate Endophytic Fungi," Studies in Mycology, Vol. 53, No. 1, 2005, pp. 173-189. doi:10.3114/sim.53.1.173

[12] K. K. Newsham, R. Upson and D. J. Read, "Mycorrhizas and Dark Septate Root Endophytes in Polar Regions," Fungal Ecology, Vol. 2, No. 1, 2009, pp. 10-20. doi:10.1016/j.funeco.2008.10.005

[13] C. C. Liang, Y. P. Xiao and Z. W. Zhao, “Arbuscular Mycorrhiza and Dark Septate Endophytes in an Abandoned Lead-Zinc Mine in Huize, Yunnan, China," Chinese Journal of Applied and Environmental Biology, Vol. 13, No. 6, 2007, pp. 811-817.

[14] Y. J. Zhang, Y. Zhang, M. J. Liu, X. D. Shi and Z. W. Zhao, "Dark Septate Endophyte (DSE) Fungi Isolated from Metal Polluted Soils: There Taxonomic Position, Tolerance, and Accumulation of Heavy Metals in Vitro," The Journal of Microbiology, Vol. 46, No. 6, 2008, pp. 624-632. doi:10.1007/s12275-008-0163-6

[15] T. Li, M. J. Liu, X. T. Zhang, H. B. Zhang, T. Sha and Z. W. Zhao, "Improved Tolerance of Maize (Zea mays L.) to Heavy Metals by Colonization of a Dark Septate Endophyte (DSE) Exophiala pisciphila," Science of The Total Environment, Vol. 409, No. 6, 2011, pp. 1069-1074. doi:10.1016/j.scitotenv.2010.12.012

[16] P. Jaeckel, G. J. Krauss and G. Krauss, "Cadmium and Zinc Response of the Fungi Heliscus lugdunensis and Verticillium cf. alboatrum Isolated from Highly Polluted Water," Science of The Total Environment, Vol. 346, No. 1-3, 2005, pp. 274-279. doi:10.1016/j.scitotenv.2004.12.082

[17] R. L. Ramos, L. A. B. Jacome, J. M. Barron, L. F. Rubio and R. M. G. Coronado, "Adsorptionof Zinc (II) from an Aqueous Solution onto Activated Carbon," Journal of Hazardous Materials, Vol. Vol. 90, No. 1, 2002, pp. 2738. doi:10.1016/S0304-3894(01)00333-8

[18] R. Chandran, A. A. Sivakumar, S. Mohandass and M. Aruchami, "Effect of Cadmium and Zinc on Antioxidant Enzyme Activity in the Gastropod, Achatina fulica," Comparative Biochemistry and Physiology Part C: Toxicology \& Pharmacology, Vol. 140, No. 3-4, 2005, pp. 422-426. doi:10.1016/j.cca.2005.04.007

[19] K. Paraszkiewicz, P. Bernat, M. Naliwajski and J. Długoński, "Lipid Peroxidation in the Fungus Curvularia lunata Exposed to Nickel," Archives of Microbiology, Vol. 192, No. 2, 2010, pp. 135-141. doi:10.1007/s00203-009-0542-3

[20] Z. Bai, L. M. Harvey and B. McNeil, "Oxidative Stress in Submerged Cultures of Fungi," Critical Reviews in Biotechnology, Vol. 23, No. 4, 2003, pp. 267-302. doi:10.1080/07388550390449294

[21] R. N. N. Abskharon, S. H. A. Hassan, M. H. Kabir, S. A. Qadir, S. M. F. G. El-Rab and M. H. Wang, "The Role of 
Antioxidants Enzymes of E. coli ASU3, a Tolerant Strain to Heavy Metals Toxicity, in Combating Oxidative Stress of Copper," World Journal of Microbiology and Biotechnology, Vol. 26, No. 2, 2010, pp. 241-247. doi:10.1007/s11274-009-0166-4

[22] S. Radić, M. Babić, D. Skobić, V. Roje and B. PevalekKozlina, "Ecotoxicological Effects of Aluminum and Zinc on Growth and Antioxidants in Lemna minor L," Ecotoxicology and Environmental Safety, Vol. 73, No. 3, 2010, pp. 336-342. doi:10.1016/j.ecoenv.2009.10.014

[23] S. Farshian, J. Khara and P. Malekzadeh, "Effect of Arbuscular Mycorrhizal (G. etunicatum) Fungus on Antioxidant Enzymes Activity under Zinc Toxicity in Lettuce Plants," Pakistan Journal of Biological Sciences, Vol. 10, No. 11, 2007, pp. 1865-1869. doi:10.3923/pjbs.2007.1865.1869

[24] P. Baptista, S. Ferreira, E. Soares, V. Coelho and M. L. Bastos, "Tolerance and Stress Response of Macrolepiota procera to Nickel," Journal of Agricultural and Food Chemistry, Vol. 57, No. 15, 2009, pp. 7145-7152. doi:10.1021/jf902075b

[25] H. Xu, P. Song, W. B. Gu and Z. R. Yang, "Effects of Heavy Metals on Production of Thiol Compounds and Antioxidant Enzymes in Agaricus bisporus," Ecotoxicology and Environmental Safety, Vol. 74, No. 6, 2011, pp. 1685-1692. doi:10.1016/j.ecoenv.2011.04.010

[26] M. Choudhary, U. K. Jetley, M. A. Khan, S, Zutshi and T. Fatma, "Effect of Heavy Metal Stress on Proline, Malondialdehyde, and Superoxide Dismutase Activity in the Cyanobacterium Spirulina platensis-S5," Ecotoxicology and Environmental Safety, Vol. 66, No. 2, 2007, pp. 204209. doi:10.1016/j.ecoenv.2006.02.002

[27] Ö. Furat and F. Kargin, "Effects of Zinc and Cadmium on Erythrocyte Antioxidant Systems of a Freshwater Fish Oreochromis niloticus," Journal of Biochemical and Molecular Toxicology, Vol. 24, No. 4, 2010, pp. 223-229. doi:10.1002/jbt.20327

[28] A. A. Fernando and R. S. Currah, "A Comparative Study of the Effects of the Root Endophytes Leptodontidium orchidicola and Phialocephala fortinii (Fungi Imperfecti) on the Growth of Some Subalpine Plants in Culture," Canadian Journal of Botany, Vol. 74, No. 7, 1996, pp. 1071-1078. doi:10.1139/b96-131

[29] A. L. Khan, M. Hamayun, N. Ahmad, M. Waqas, S. M. Kang, Y. H. Kim and I. J. Lee, "Exophiala sp. LHL08 Reprograms Cucumis sativus to Higher Growth under Abiotic Stresses," Physiologia Plantarum, Vol. 143, No. 4, 2011, pp. 329-343. doi:10.1111/j.1399-3054.2011.01508.x

[30] A. L. Khan, M. Hamayun, M. Waqas, S. M. Kang, Y. H. Kim, D. H. Kim and I. J. Lee, "Exophiala sp. LHL08 Association Gives Heat Stress Tolerance by Avoiding Oxidative Damage to Cucumber Plants," Biology and Fertility of Soils, Vol. 48, No. 5, 2012, pp. 519-529. doi:10.1007/s00374-011-0649-y

[31] D. H. Marx, "The Influence of Ectotrophic Ectomycorrhizal Fungi on the Resistance of Pine Roots to Pathogenic Infections. I. Antagonism of Mycorrhizal Fungi to Pathogenic Fungi and Soil Bacteria," Phytopathology,
Vol. 59, No. 4, 1969, pp. 153-163.

[32] P. Lankinen, M. A. Kähkönen, J. Rajasärkkä, M. Virta and A. Hatakka, "The Effect of Nickel Contamination on the Growth of Litter-Decomposing Fungi, Extracellular Enzyme Activities and Toxicity in Soil," Boreal Environment Research, Vol. 16, No. 3, 2011, pp. 229-239.

[33] C. Collin-Hansen, R. A. Andersen and E. Steinnes, "Molecular Defense Systems Are Expressed in the King Bolete (Boletus edulis) Growing near Metal Smelters," Mycologia, Vol. 97, No. 5, 2005, pp. 973-983. doi:10.3852/mycologia.97.5.973

[34] M. Vallino, E. Martino, F. Boella, C. Murat, M. Chiapello and S. Perotto, " $\mathrm{Cu}, \mathrm{Zn}$ Superoxide Dismutase and Zinc Stress in the Metal-Tolerant Ericoid Mycorrhizal Fungus Oidiodendron maius Zn," FEMS Microbiology Letters, Vol. 293, No. 1, 2009, pp. 48-57. doi:10.1111/j.1574-6968.2009.01503.x

[35] J. V. Colpaert, L. A. H. Muller, M. Lambaerts, K. Adriaensen and J. Vangronsveld, "Evolutionary Adaptation to Zn Toxicity in Populations of Suilloid Fungi," New Phytologist, Vol. 162, No. 2, 2004, pp. 549-560. doi:10.1111/j.1469-8137.2004.01037.x

[36] J. W. G. Cairney, D. M. V. Leerdam and D. M. Chen, "Metal Insensitivity in Ericoid Mycorrhizal Endophytes from Woollsia pungens (Epacridaceae)," Australian Journal of Botany, Vol. 49, No. 5, 2001, pp. 571-577. doi:10.1071/BT01005

[37] L. Ezzouhri, E. Castro, M. Moya, F. Espinola and K. Lairini, "Heavy Metal Tolerance of Filamentous Fungi Isolated from Polluted Sites in Tangier, Morocco," African Journal of Microbiology Research, Vol. 3, No. 2, 2009, pp. 35-48.

[38] L. A. H. Muller, A. R. Craciun, J. Ruytinx, M. Lambaerts, N. Verbruggen, J. Vangronsveld and J. V. Colpaert, "Gene Expression Profiling of a Zn-Tolerant and a Zn-Sensitive Suillus luteus Isolate Exposed to Increased External Zinc Concentrations," Mycorrhiza, Vol. 17, No. 7, 2007, pp. 571-580. doi:10.1007/s00572-007-0134-5

[39] G. M. Gadd, "Interaction of Fungi with Toxic Metals," New Phytologist, Vol. 124, No. 1, 1993, pp. 25-60. doi:10.1111/j.1469-8137.1993.tb03796.x

[40] J. A. Sayer and G. M. Gadd, "Solubilization and Transformation of Insoluble Inorganic Metal Compounds to Insoluble Metal Oxalates by Aspergillus niger," Мyсоlogical Research, Vol. 101, No. 6, 1997, pp. 653-661. doi:10.1017/S0953756296003140

[41] M. González-Guerrero, L. H. Melville, N. Ferrol, J. N. A. Lott, C. Azcón-Aguilar and R. L. Peterson, "Ultrastructural Localization of Heavy Metals in the Extraradical Mycelium and Spores of the Arbuscular Mycorrhizal Fungus Glomus intraradices," Canadian Journal of Microbiology, Vol. 54, No. 2, 2008, pp. 103-110. doi:10.1139/W07-119

[42] H. Zhao and D. Eide, "The ZRT2 Gene Encodes the Low Affinity Zinc Transporter in Saccharomyces cerevisiae," The Journal of Biological and Chemistry, Vol. 271, No. 2, 1996, pp. 23203-23210.

[43] L. A. Gaither and D. J. Eide, "Eukaryotic Zinc Transporters and Their Regulation," BioMetals, Vol. 14, No. 3-4, 
2001, pp. 251-270. doi:10.1023/A:1012988914300

[44] S. R. Powell, "The Antioxidant Properties of zinc," The Journal of Nutrition, Vol. 130, No. 5, 2000, pp. 1447s$1454 \mathrm{~s}$.

[45] G. M. Zeng, A. W. Chen, G. Q. Chen, X. J. Hu, S. Guan, C. Shang, L. H. Lu and Z. J. Zou, "Responses of Phanerochaete chrysosporium to Toxic Pollutants: Physiological Flux, Oxidative Stress, and Detoxification," Environmental Science and Technology, Vol. 46, No. 14, 2012, pp. 7818-7825. doi:10.1021/es301006j

[46] P. P. Alia Saradhi and P. Mohanty, "Proline in Relation to Free Radical Production in Seedlings of Brassica juncea Raised under Sodium Chloride Stress," Plant and Soil, Vol. 155-156, No. 1, 1993, pp. 497-500. doi:10.1007/BF00025092

[47] F. R. Cavalcanti, J. T. A. Oliveira, A. S. Martins-Miranda, R. A. Viégas and J. A. G. Silveira, "Superoxide Dismutase, Catalase and Peroxidase Activities Do Not Confer Protection against Oxidative Damage in Salt-Stressed Cowpea Leaves," New Phytologist, Vol. 163, No. 3, 2004, pp. 563-571. doi:10.1111/j.1469-8137.2004.01139.x

[48] N. Ercal, H. Gurer-Orhan and N. Aykin-Burns, "Toxic Metals and Oxidative Stress Part I: Mechanisms Involved in Metal-Induced Oxidative Damage," Current Topics in Medicinal Chemistry, Vol. 1, No. 6, 2001, pp.529-539. doi:10.2174/1568026013394831

[49] M. J. Penninckx, “An Overview on Glutathione in Saccharomyces versus Non-Conventional Yeasts," FEMS Yeast Research, Vol. 2, No. 3, 2002, pp. 295-305.

[50] M. M. Azevedo, A. Carvalho, C. Pascoal, F. Rodrigues and F, Cássio, "Responses of Antioxidant Defenses to $\mathrm{Cu}$ and $\mathrm{Zn}$ Stress in Two Aquatic Fungi," Science of The Total Environment, Vol. 377, No. 2-3, 2007, pp. 233-243. doi:10.1016/j.scitotenv.2007.02.027

[51] E. Z. Krumova, S. B. Pashova, P. A. Dolashka-Angelova, T. Stefanova and M. B. Angelova, "Biomarkers of Oxidative Stress in the Fungal Strain Humicola lutea under Copper Exposure," Process Biochemistry, Vol. 44, No. 3, 2009, pp. 288-295. doi:10.1016/i.procbio.2008.10.023 